\title{
ЮРИДИЧНІ ГАРАНТІЇ РЕАЛІЗАЦІї ТРУДОВИХ ПРАВ БІЖЕНЦІВ ТА ОСІБ, ЯКІ ПОТРЕБУЮТЬ ДОДАТКОВОГО ЗАХИСТУ
}

\author{
ПАВЛІЧЕНКО Ірина Миколаївна - старший викладач кафедри права та \\ правоохоронної діяльності Державного університету «Житомирська політехніка» \\ УДК 349.2 \\ DOI 10.32782/NP.2021.2.5
}

У статті, спираючись на аналіз наукових поглядів ечених та норм чинного законодавства, розглянуто питання юридичних гарантій реалізащї трудових прав біжениів та осіб, які потребують додаткового захисту.

Встановлено, щзо юридичні гарантї реалізачиї трудових прав біженців та осіб, які потребують додаткового захисту - иее сукупність борм, засобів, заходів та умов, що сприяють здійсненню та забезпеченню права на прачю, його захисту та охороні, а також виконанню кореспондуючих обов'язків учасників трудових правовідносин, однією зі сторін яких є біженецьв або особа, яка потребує додаткового заxисту.

Підкреслено, що юридичні гарантї реалізащиі трудових прав біжениів та осіб, які потребують додаткового захисту на съогодні, на жаль, можна оцінити як низъкі, а тому національне трудове законодавство у изй сфері потребує подальшого доопрацювання, удосконалення та гармонізащії із міжнародним законодавством.

Надано пропозиий щзодо вдосконалення національного трудового законодавства у досліджуваній сбері та запропоновано внести зміни до норм чинного законодавства з метою його вдосконалення, гармонізачй та приведення у відповідність до міжнародних стандартів у сфбері праuі.

Ключові слова: біжениі, гарантї, законодавство, особа, яка потребує додаткового захисту, трудові права, трудове право, правове регулювання, юридичні гарантї, юридичні гарантї трудових прав.
Постановка проблеми

Численні військові та політичні конфлікти е світі, систематичні порушення прав людини, переслідування через ознаки раси, віросповідання, національності, політичні переконання, а також інші види дискримінації, призводять до того, що велика кількість людей вимушено покидає країну свого постійного місця проживання та шукає притулку в інших державах. Наплив біженців та осіб, які потребують додаткового захисту, є проблемою не лише для країн Европи та далекого зарубіжжя, а й для України. Проблеми у цій сфері викликають труднощі не лише економічного, соціального та психологічного характеру для цих категорій осіб, а й для країни, що надає їм притулок та захист. Прибувши до іншої держави, людина зіштовхується 3 рядом проблем, однією із найважливіших серед яких $\epsilon$ реалізація права на працю, за допомогою якої вони можуть забезпечити собі та своїм родинам гідний рівень життя. А тому питання юридичних гарантій трудових прав біженців та осіб, які потребують додаткового захисту, є актуальним та потребує науково-теоретичного осмислення та обгрунтування.

\section{Аналіз останніх досліджень і публікацій}

Питання, що стосуються юридичних гарантій реалізації трудових прав біженців та осіб, які потребують додаткового захисту, були предметом дослідження бага- 
тьох вітчизняних та зарубіжних науковців. Проблемою визначення, систематизації та актуалізації понятійно-категоріального апарату юридичних гарантій реалізації трудових прав та їх класифікації в тій чи іншій мірі займалися такі науковці, як: В. М. Андріїв, А. О. Бабенко, П. А. Бущенко, В. С. Венедіктов, В. В. Жернаков, М. І. Іншин, К. Ю. Мельник, А. М. Островерх, С. М. Прилипко, В. М. Скобєлкін, О. П. Смирнов, Н. М. Хуторян, I. І. Чанишева, О. М. Ярошенко та багато інших. Втім, незважаючи на численні наукові здобутки, ця проблематика не втратила своєї актуальності. Окрім того, справедливим буде вказати на той факт, що проблема юридичних гарантій реалізації трудових прав біженців та осіб, які потребують додаткового захисту належної уваги у наукових працях вітчизняних учених, не отримала грунтовного науково-теоретичного дослідження.

Метою даної статті $\boldsymbol{\epsilon}$ комплексне науково-теоретичне дослідження проблеми юридичних гарантій реалізації трудових прав біженців та осіб, які потребують додаткового захисту, а також визначення дефініцій основних понять у цій сфері.

\section{Виклад основного матеріалу}

Перш ніж розглянути поняття «юридичні гарантії реалізації трудових прав біженців та осіб, які потребують додаткового захисту», доцільно з'ясувати сутність поняття «біженці» та «особи, які потребують додаткового захисту». Поняття «біженці» у науковій літературі трактується по-різному. Зокрема, Академічний тлумачний словник української мови надає наступне визначення: «біженці»- це люди, які залишають місце свого проживання під час війни або стихійного лиха [1]. Вперше поняття «біженець» було закріплено на міжнародному рівні у Конвенції про статус біженців 1951 року. Після цього дефініція зазначеного поняття була імплементована до законодавства багатьох країн світу. У 2002 році був прийнятий Закон України «Про біженців», який уперше закріпив поняття «біженець» у національному за- конодавстві, у подальшому набув чинності Закон України «Про біженців та осіб, які потребують додаткового або тимчасового захисту», який діє і сьогодні. Так, відповідно до Закону України «Про біженців та осіб, які потребують додаткового або тимчасового захисту» «біженець» - особа, яка не $\epsilon$ громадянином України і внаслідок обгрунтованих побоювань стати жертвою переслідувань за ознаками раси, віросповідання, національності, громадянства (підданства), належності до певної соціальної групи або політичних переконань перебуває за межами країни своєї громадянської належності та не може користуватися захистом цієї країни або не бажає користуватися цим захистом внаслідок таких побоювань, або, не маючи громадянства (підданства) і перебуваючи за межами країни свого попереднього постійного проживання, не може чи не бажає повернутися до неї внаслідок зазначених побоювань (ст. 1) [2]. Із зазначеного вбачається, що біженець це: по-перше, особа, яка шукає притулку у країні, громадянином якої вона не є; подруге, така особа зазнає переслідувань або має обгрунтовані побоювання таких переслідувань за певними критеріями, зокрема, ознаками раси, віросповідання, національності, політичних переконань тощо; i, по-третє, особа не може користуватися захистом країни свого підданства або не бажає $з$ особистих причин користуватися таким захистом.

Надаючи особі статус біженця, Україна надає захист іноземним громадянам і особам без громадянства, які шукають захисту на їі території. Окрім того, національне законодавство додатково передбачає іншу форму захисту для осіб - шукачів притулку, зокрема, надання статусу особи, яка потребує додаткового захисту. Так, згідно зі ст. 1 Закону України «Про біженців та осіб, які потребують додаткового або тимчасового захисту», особа, яка потребує додаткового захисту, - це особа, яка не є біженцем відповідно до Конвенції про статус біженців 1951 року і Протоколу щодо статусу біженців 1967 року та цього Закону, але потребує захисту, оскільки така особа змушена була прибути в Україну або зали- 


\section{Теорія, історія держави і права, конституційне право}

шитися в Україні внаслідок загрози їі життю, безпеці чи свободі в країні походження через побоювання застосування до неї смертної кари або виконання вироку про смертну кару чи тортур, нелюдського або такого, що принижує гідність, поводження чи покарання або загальнопоширеного насильства в ситуаціях міжнародного або внутрішнього збройного конфлікту чи систематичного порушення прав людини i не може чи не бажає повернутися до такої країни внаслідок зазначених побоювань [2]. Закріплення Україною додаткових форм захисту для осіб - шукачів притулку - 6 намагання законодавця наблизити національне законодавство до міжнародних стандартів у цій сфері.

Важливо зазначити, що після надання особі статусу біженця або особи, яка потребує додаткового захисту, коло ії прав та обов'язків розширюється, порівняно 3 особами, яким такий статус ще не присвоєно. Зокрема, такі особи мають рівні з громадянами України права на: пересування; вільний вибір місця проживання; вільне залишення території України, крім обмежень, встановлених законом; працю; провадження підприємницької діяльності, не забороненої законом; охорону здоров'я; медичну допомогу та медичне страхування; відпочинок; освіту; свободу світогляду та віросповідання тощо (ст. 15) [2]. Отже, біженцям та особам, які потребують додаткового захисту, згідно з нормами чинного законодавства належні як загальні права та свободи, передбачені для громадян України та інших категорій осіб, що перебувають на іiі території, а також спеціальні права, обумовлені особливим правовим статусом досліджуваної категорії осіб.

Україна, проголосивши себе демократичною, правовою, соціальною державою, визнала людину, іï права, свободи, інтереси, соціальну рівність найвищою соціальною цінністю в нашій державі. Гарантії дотримання прав і свобод осіб визначають спрямованість нашої держави [3]. А відтак, правове регулювання у сфері прав людини спрямоване на встановлення, визнання і захист прав людини, що має гарантувати усім людям гідне життя, тобто безпечне, матеріально забезпечене і здорове. Отримавши закріплення в Конституції України, права людини визначають межі цих прав, можливість користування благами для задоволення своїх інтересів [4, с. 44].

3 огляду на зазначене вище, можемо констатувати, що гарантування прав і свобод людини є актуальним питанням для будь-якої правової держави, особливо у випадку біженців та осіб, які потребують додаткового захисту, враховуючи вразливість такої категорії осіб. Саме тому питання гарантій реалізації прав і свобод 6 ключовим для будь-якої галузевої науки, зокрема і для трудового права. Щодо визначення поняття «гарантії» точки зору науковців дещо різняться, а тому розглянемо деякі з них.

Так, Е. В. Білозьоров під гарантіями розуміє цілу низку конкретних засобів, завдяки яким стає реальним ефективне здійснення громадянами своїх прав і свобод, їх охорона та захист від правопорушення. Їх головне призначення, на думку автора, 3 якою ми погоджуємося, полягає у забезпеченні всіх і кожного рівними правовими можливостями для набуття, реалізації, охорони та захисту суб'єктивних прав i свобод [5, с. 27]. У свою чергу, С. В. Селезень вказує, що «гарантії - це закріплені в законодавстві умови та засоби, що забезпечують суб'єктам трудових і похідних від них правовідносин реальні можливості для охорони, безперешкодного здійснення, відновлення (у випадку порушення) їх суб'єктивних прав i належного виконання ними обов'язків [6, с. 34]. А. В. Котова зазначає, що гарантії прав та свобод - це обов'язки держави захищати людину, створювати правові, соціальні і культурні умови для реалізації їі прав і свобод, а також діяльність міжнародних і державних організацій із захисту прав людини [7,c. 507-508].

Враховуючи зазначене, можемо говорити про те, що гарантії - це сукупність засобів та способів реалізації суб'єктивних прав та обов'язків людини. У свою чергу, юридичні гарантії $\epsilon$ складовою гарантій прав, свобод та законних інтересів людини і громадянина. Більшість учених-пра- 
вознавців доходить висновку щодо поділу гарантій на загальні та спеціальні. За загальним правилом, до спеціальних науковці відносять юридичні (правові) гарантії.

П. М. Рабінович під юридичними гарантіями розуміє «засоби, за допомогою яких втілюється, охороняється, а у випадках порушення відновлюється режим законності [8, с. 83]. А. В. Пономаренко запропонував розглядати юридичні гарантії як відображену у нормативно-правових актах сукупність умов, способів та засобів, за допомогою яких визначається порядок реалізації, здійснення прав і свобод особи, а також їх охорони, захисту та відновлення у разі порушення [9, с. 39]. Отже, завдяки юридичним гарантіям здійснюються, реалізуються та охороняються права, інтереси та обов'язки людини, передбачені нормативно-правовими актами. Дещо іншої точки зори дотримується О. В. Міцкевич, який під юридичними гарантіями розуміє встановлений державою порядок діяльності державних органів та установ, громадських організацій, спрямований на попередження й припинення посягань на права громадян, на відновлення цих прав і залучення до відповідальності за порушення цих прав [10, с. 16].

Із вищевикладеного вбачається, що погляди науковців на визначення поняття «юридичні гарантії» різняться. Так, одна група науковців схиляеться до точки зору, що юридичні гарантії - це норми-принципи, які знаходять своє відображення у чинних нормативно-правових актах, а інша група вчених до складу юридичних гарантій включає порядок діяльності державних органів, органів місцевого самоврядування, громадських організацій тощо. В. М. Андріїв, у свою чергу, юридичні гарантії поділяє на два види: по-перше, гарантії, закріплені в нормах - принципах; по-друге, організаційно - правові гарантії прав та свобод людини і громадянина. Вчена зазначає, що першочерговим видом юридичних гарантій є нормипринципи, зокрема, ті, які забезпечують права та свободи людини і громадянина, щодо непорушності, невичерпності, рівності, необмеженості конституційних прав і свобод людини і громадянина. До іншого виду юридичних гарантій дослідниця відносить організаційно-правові гарантії прав та свобод людини і громадянина, а саме діяльність державних органів та громадських організацій щодо забезпечення, реалізації та охорони прав і свобод людини і громадянина [11, с. 15].

Отже, юридичні гарантії - це сукупність визначених у нормативно-правових актах умов та засобів, що забезпечують реалізацію прав, свобод, інтересів та обов'язків усіх суб'єктів права. Одним із видів спеціальних юридичних гарантій 6 трудові юридичні гарантії. Поняття юридичних гарантій реалізації трудових прав також визначається вченими у сфері трудового права по-різному. На переконання В. М. Андріїв, «юридичні гарантії трудових прав працівників - це така система умов, способів, прийомів та форм, яка покликана охороняти, захищати ці права, забезпечувати їх безперешкодну реалізацію та виконання кореспондуючих останнім обов'язків» [11, с. 18]. О. В. Кузніченко зазначає, що найважливіша функція гарантій трудових прав працівників, як правових засобів, полягає в досягненні ними цілей правового регулювання. Вона виявляється в тому, що в результаті реалізації правових засобів забезпечується рух i захист трудових прав і законних інтересів працівників, гарантується їх законне і справедливе задоволення [12, с. 27].

Отже, юридичні гарантії реалізації трудових прав - це закріплена у нормах чинного трудового законодавства сукупність інструментів та засобів, використання яких дозволяє забезпечити безперешкодне здійснення та реалізацію таких прав. Основне призначення відповідних юридичних гарантій полягає в охороні та захисті трудових прав і законних інтересів працівників, а також у забезпеченні виконання обов'язків сторін трудових правовідносин.

Біженці та особи, які потребують додаткового захисту, володіють певним обсягом трудових прав, 3 урахуванням їх особливого правового статусу. Утім, 3 перших днів присвоєння статусу таким 


\section{Теорія, історія держави і права, конституційне право}

категоріям осіб, перед біженцями та особами, які потребують додаткового статусу, постає ряд проблем, зокрема можливість знайти роботу ускладнюється проблемами дискримінації трудових прав таких осіб. Така проблема може виникати через брак інформації у роботодавця щодо досвіду роботи, знань, умінь, кваліфікації такого працівника, адже освіту та досвід роботи така особа отримувала за кордоном. Часто причиною дискримінації у цій сфері є мовний бар'єр або банальне небажання роботодавців брати на роботу таку категорію осіб. А тому юридичні гарантії реалізації трудових прав біженців та осіб, які потребують додаткового захисту, відіграють важливу роль у захисті та охороні їх трудових прав, а також у забезпеченні виконання кореспондуючих обов'язків усіх учасників трудових правовідносин.

Юридичні гарантії реалізації трудових прав біженців також слід віднести до спеціальних гарантій. До юридичних гарантій належить система засобів правової охорони особистості та засобів їх правомірної реалізації. Це означає, що норми міжнародного і внутрішньодержавного права, закріплені в них юридичні засоби спрямовані на конкретизацію прав, свобод i обов’язків людини, визначення порядку їх охорони і захисту [13, с. 162]. Основними міжнародними документами, що гарантують дотримання прав біженців нарівні 3 іншими категоріями населення, є: Загальна декларація прав людини (1948р.); Міжнародний пакт про громадянські та політичні права (1966р.); Міжнародна конвенція про ліквідацію усіх форм расової дискримінації (1965р.); Міжнародний пакт про економічні, соціальні та культурні права (1966 р.); Конвенція ООН про статус біженців (1951р.); Протокол щодо статусу біженців (1966 р.) тощо.

Національною базовою юридичною основою, що містить правові норми, пов'язані $з$ реалізацією трудових прав біженців, є: Конституція України; Кодекс законів про працю України; Закон України «Про приєднання України до Конвенції про статус біженців та Протоколу щодо статусу біженців»; Закон України «Про бі- женців та осіб, які потребують додаткового або тимчасового захисту»; Закон України «Про зайнятість населення» тощо.

Конституція України гарантує: «Іноземці та особи без громадянства, що перебувають в Україні на законних підставах, користуються тими самими правами і свободами, а також несуть такі самі обов'язки, як і громадяни України, - за винятками, встановленими Конституцією, законами чи міжнародними договорами України» (ст. 26), а отже, біженці та особи, які потребують додаткового захисту, які перебувають на території України, наділені тими самими правами, що і громадяни України. До того ж, Конституція України захищає біженців та осіб, які потребують додаткового захисту, від будь-яких проявів дискримінації, проголошуючи, що «не може бути привілеїв чи обмежень за ознаками раси, кольору шкіри, політичних, релігійних та інших переконань, статі, етнічного та соціального походження, майнового стану, місця проживання, за мовними або іншими ознаками» (ст. 24) [3].

На жаль, Кодекс законів про працю України [14] окремо не встановлює юридичних гарантій реалізації трудових прав біженців та осіб, які потребують додаткового захисту. Утім, норми цього нормативноправового акту регулюють трудові відносини всіх працівників, тобто і на біженців та осіб, які потребують додаткового захисту. До того ж, положеннями Кодексу законів про працю встановлена заборона будьякої дискримінації у сфері праці. 3 метою вдосконалення національного трудового законодавства, видається доцільним доповнити Кодекс законів про працю України статтею, що встановлює юридичні гарантії реалізації трудових прав біженців та осіб, які потребують додаткового захисту.

Особа, яку визнано біженцем, або особою, яка потребує додаткового захисту, має рівні права 3 громадянами України, зокрема на працю (ст. 15) [2]. Відповідно до статті 42 Закону України «Про зайнятість населення» роботодавці мають право на застосування праці іноземців та осіб без громадянства на території України на підставі дозволу, що видається територі- 
альними органами центрального органу виконавчої влади, що реалізує державну політику у сфері зайнятості населення та трудової міграції. Без такого дозволу здійснюеться працевлаштування, зокрема іноземців та осіб без громадянства, які набули статусу біженця або особи, яка потребує додаткового захисту, відповідно до законодавства України [15].

\section{Висновки}

Проведений вище аналіз дає змогу констатувати, що біженці та особи, які потребують додаткового захисту, є для України важливим трудовим ресурсом, особливо в умовах значного відтоку робочої сили за межі нашої держави. Однак, при цьому практика свідчить про те, що біженці та особи, які потребують додаткового захисту, в нашій країні стикаються 3 низкою проблем при реалізації свого права на працю. В окремих випадках, мова йде про неможливість офіційного працевлаштування, невиплату їм заробітної плати, неналежний соціальний захист тощо.

Враховуючи вищевикладене, можна дійти висновку, що юридичні гарантії реалізації трудових прав біженців та осіб, які потребують додаткового захисту, - це сукупність форм, засобів, заходів та умов, що сприяють здійсненню та забезпеченню права на працю, його захисту та охороні, а також виконанню кореспондуючих обов'язків учасників трудових правовідносин, однією зі сторін яких є біженець, або особа, яка потребує додаткового захисту. Доцільно підкреслити, що юридичні гарантії реалізації трудових прав біженців та осіб, які потребують додаткового захисту, на сьогодні, на жаль, можна оцінити як низькі. А тому національне трудове законодавство у цій сфері потребує подальшого доопрацювання, удосконалення та гармонізації із міжнародним законодавством.

\section{Література}

1. Академічний тлумачний словник української мови. URL: http://sum.in.ua (дата звернення 29.02.2021).

2. Про біженців та осіб, які потребують додаткового або тимчасового захисту:
Закон України від 08.07.2011 № 3671-VI. Офічійний вісник України. 2011. № 59. Ст. 2347.

3. Конституція України: Закон№ 254к/96-ВР від 28.06.1998. Відомості Верховної Ради України. 1996. № 30. Ст. 141.

4. Чулінда Н. І. Соціальні права людини. Актуальні проблеми соцуільного права. Випуск II: науково-практичний посібник (збірник статей учасників Всеукраїнських соціальних програм (заходів) ВГОI «Інститут реабілітації та соціальних технологій» у 2015 р.) / за заг. ред. М. І. Іншина, В. А. Костюка, В. П. Мельника. К.: ПВГОІ «ІР СТ Україна», 2016. 220 с.

5. Білозьоров E. В. Правові гарантії захисту прав і свобод людини в Україні: peалії та проблеми. Адвокат. 2009. № 8 (107). C. 26-30.

6. Селезень С. В. Юридичні гарантії захисту трудових прав працівників. Актуальні проблеми вітчизняної юриспрудениії. 2016. № 5. С. 33-36.

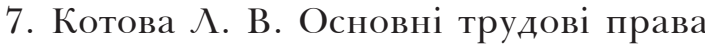
робітника: правова природа та перспективи розвитку. Форум права. 2011. № 1.С. 507-515.

8. Рабінович П. М. Основи загальної теорії права та держави: навч. посібн. Вид. 9-те, зі змінами. Аьвів: Край, 2007. 192 с.

9. Пономаренко А. В. Поняття «юридичні гарантії» в трудовому праві. Збірник наукових пращь Харківсъкого національного педагогічного університету ім. Г. С. Сковороди. «Право». 2013. Вип. 20. С. 37-41. URL: http://nbuv.gov.ua/UJRN/znpkhnpu_ pravo_2013_20_8 (дата звернення 29.04.2021).

10. Мицкевич А. В. О гарантиях прав и свобод советских граждан в общенародном социальном государстве. Советское государство и право. 1963. № 8. С. 15-21.

11. Андріїв В. М. Юридичні гарантії захисту трудових прав працівників. Форум права. 2001. № 4. С. 15-20.

12. Кузниченко О. В. Правовые вопросы процесуального обеспечения реализации трудових прав работников. Актуальні проблеми науки трудового права в сучасних умовах ринкової економіки: матеріали науково-практичної конференції, м. Харків, 


\section{Теорія, історія держави і права, конституційне право}

19-20 травня 2003 р. Харків: Українська асоціація фахівців трудового права, Національний університет внутрішніх справ. 2003. C. 27.

13. Пожарова О., Пожаров Ю. Юридичні гарантії трудових прав жінок: міжнародні акти та законодавство України. Підприємниитво, господарство і право. 2020. № 2. C. 160-164.

14. Кодекс законів про працю України: Закон України від 10.12.1971 № 322VIII. Відомості Верховної Ради УРСР від 17.12.1971. Додаток до № 50.

15. Про зайнятість населення: Закон України від 05.07.2012 № 5067-VI. Вiдомості Верховної Ради Украӥни. 2013. № 24.Cт. 243.
Based on the analysis of scientific views of scholars and the norms of current legislation, the author of the article has studied the issue of legal guarantees for the realization of labor rights of refugees and persons requiring additional protection.

It has been proven that the range of the rights and responsibilities, after a person is granted the refugee status or the status of a person requiring additional protection, is expanded compared to those who have not been granted such status yet. In accordance with the current legislation refugees and persons requiring additional protection have both general rights and freedoms provided for citizens of Ukraine and other categories of persons staying on its territory and special rights due to the special legal status of the studied category of persons.

It has been established that legal guarantees for the realization of labor rights of refugees and persons requiring additional protection are a set of forms, means, measures and conditions that promote the exercise and provision of the right to work, its protection and defense, as well as the corresponding duties of the participants of labor legal relations, one of the parties to which is a refugee or a person requiring additional protection.

It has been emphasized that the legal guarantees for the realization of labor rights of refugees and persons requiring additional protection unfortunately can be currently assessed as low and therefore, national labor legislation in this area needs further refinement, improvement and harmonization with international law.

The author has provided propositions for improving national labor legislation in the studied area and has offered to amend the norms of the current legislation in order to improve, harmonize and bring it into line with international labor standards. In particular, it has been offered to supplement the Labor Code of Ukraine with the Article establishing legal guarantees for the realization of labor rights of refugees and persons requiring additional protection.

Key words: refugees, guarantees, legislation, a person requiring additional protection, labor rights, labor law, legal regulation, legal guarantees, legal guarantees of labor rights. 